\title{
Um pouco da minha infância
}

JOSÉ NUNES DE OLIVEIRA

$\mathrm{E}$

U, José NUNES DE Oliveira, sou índio da tribo Kariri-Xocó, localizada no município de Porto Real do Colégio, estado de Alagoas.

$\mathrm{Na}$ realidade, a história das origens dos meus pais é, em certa medida, da homogeneização dos meus avós em cruzamentos de etnias diferentes entre Kariri, Natu, Xocó e Pankararu que habitaram as margens do rio São Francisco desde os tempos imemoriais, atualmente sob o denominativo genérico de índios Kariri-Xocó.

Meus pais são Alírio Nunes Pires e Maria de Lurdes Ferreira. Segundo as histórias da minha avó Júlia Pires, mãe de meu pai, de origem Xocó, ela era filha de Ormina Pires, filha caçula de Inocêncio Pires, meu tataravô, que foi o chefe tribal desse grupo no século XIX. O próprio Inocêncio Pires era filho de uma índia Xocó com José Ribeiro Sabino Pires, índio Pankararu de Pernambuco que chegou na ilha de São Pedro de Porto da Folha e construiu sua família.

\section{Meu nascimento}

Minha mãe teve uma gravidez difícil. Não comia muito bem, tinha fastio e enjoava; num alguidar com farinha, às vezes beliscava moqueca de peixe miúdo, mingau de milho ralado. $\mathrm{O}$ alimento preferido de minha mãe gestante era a água do rio São Francisco quando descia o barranco. "Água de pote fedia nas ventas", ela dizia; o rio era cheiroso quando ela vinha beber, chegava na beiradinha e ficava saciada.

Nessa mesma época, estava para chegar um irmão de minha mãe chamado Jurandir, que foi embora há muitos anos para Manaus, no Amazonas. Era primeiro tenente das Forças Armadas; não sei dizer de qual polícia: Marinha, Exército ou Aeronáutica. O dia em que ele chegou de viagem, foi o dia em que nasci: aos 10 de setembro de 1963. Trouxe vários presentes para toda a família, inclusive um enxoval para recémnascido, para uma irmã gestante ou que estivesse parida. No momento, fui eu o tal escolhido.

A parteira do caso foi a velha Nenê, assim conhecida por todos de Colégio. O menino que nascera era magrinho, dizia o povo que chegava em visita à mamãe na aldeia arruada. 


\section{Minhas lembranças}

A lembrança mais remota que tenho no entendimento é de quando eu era criança, chorando numa rede. Mamãe pegou-me nos braços e me colocou no chão: saí caminhando, começava a brincar. Outra vez, ainda me lembro, foi na casa de meu avô Euclides: ele estava deitado e doente. Eu ficava no quarto e ele se assentava. Minha avó Pureza lhe dava mingau no prato e ele começava a comer. No corredor da casa tinha uma canoa de pesca que estava encostada que o pescador não mais usava: remo, cuia e uma tarrafa. Quando Euclides morreu em 1966, eu tinha três anos de idade.

A casa onde eu morava já era de telha e taipa, bem vizinha à nossa escola da aldeia, construída desde o tempo do SPI; na frente, do outro lado da rua, era a casa de Analbertino, homem já velho na idade; era filho de Inocêncio Pires, tio de minha avó Júlia. Encostado, morava o cacique Otávio, irmão do pajé Francisquinho. No canto do quintal existia uma ingazeira, em cuja sombra eu brincava com meus dois irmãos: Lurdinha e Antônio, ambos surdos e mudos.

Segundo história de Antônio Nunes, irmão de meu pai, embaixo dessa velha Ingazeira, em 1944, Otávio foi escolhido pela comunidade indígena para ser o cacique tribal. Ainda no quintal, existia um velho pé de jenipapo no qual pousavam pássaros: vim-vim, bem-te-vi, assanhaço, pintassilgo, entre outros. Os meus pais foram, na minha infância, os primeiros educadores na formação de minha conduta perante os mais velhos, comunidade indígena e família. Mas na minha vida de criança, o cacique Otávio Queiroz Nidé instruiu-me no conhecimento tradicional de nosso povo indígena, cultura, costumes e organização tribal.

Meu avô paterno havia morrido, mesmo muito antes de eu nascer; o avô materno morreu quando eu só tinha três anos. Otávio foi para mim como o avô que conheci e me ensinou, antes mesmo de freqüentar a escola indígena que ficava ao lado da minha casa. Aprendi que devemos imitar os mais velhos para a cultura continuar; ouvir as histórias para um dia contar, fazer arcos, flechas, o jereré.

Quando eu ia a sua casa ou ele ia na minha, eu perguntava sobre as coisas. O jenipapo... O fruto maduro serve para comer... Isso eu fiquei sabendo pela minha mãe, mas o Otávio me ensinou que o fruto verde do jenipapo ralado, espremido o bagaço, dava uma tinta escura preta azulada com que os antigos se pintavam. O caldo escorrido era colocado no fogo numa panela de barro só para mornar; tirava o caldo do fogo e deixava de 
molho uma noite: pronto para ser usado no corpo. Uma vez fiz para aprender; passaram-se muitos dias para sair a tintura do corpo. Só saiu com o passar do tempo, não continuando a renovar os traços.

Como aconteceu em Sergipe com os Xocó, as aldeias indígenas foram extintas legalmente em Alagoas no ano de 1873. A expropriação levou, ao longo dos anos, a população indígena a se fixar em Porto Real do Colégio, numa rua da periferia da cidade, perpendicular ao rio São Francisco. A aldeia dos índios situada na rua da cidade de Porto Real do Colégio foi o cenário da história da vida em comunidade de nosso povo sofrido, junto com o Ouricuri, unindo a todos na preservação de nossas crenças, costumes e cultura.

Eis a aldeia segundo a tradição dos velhos: casas de taipa cobertas de palha, rua de terra batida, arvoredos de pés de ingazeiras em cujas sombras existiam pilões, também pontos de reuniões, conversas. Meninos nus, descalços, brincando; índias trabalhando na cerâmica utilitária, homens chegando da pescaria.

Nesse meio foram criados meus pais; num sentimento de amor cresceram juntos, com a perspectiva de fundar uma nova família. Em 1941 casaram-se Maria de Lurdes e Alírio, meus pais. Numa casinha de palha também foram morar: uma cama de vara, fogo de lenha no chão, vasilhames de barro, potes e pratos, todos feitos pelas mãos de minha mãe, completavam a arrumação, juntamente com os artifícios de pesca trabalhados por meu pai: jereré, kuvú, tarrafa e puçá.

A família é a unidade do povo, mas a riqueza da comunidade não é o poder econômico do casal. Grande número de filhos constitui a maior fortuna e respeito na posição

\section{Guardião da história*}

Nunes é das beiradas do rio de São Francisco. Passei um bom tempo conversando com ele e tentando conseguir que assentasse suas lembranças num pedaço de papel. Hoje em dia, ele escreve e eu apenas digito. Devo dizer, que as reticências no texto são minhas e são coisas de cabeça seca. Por outro lado, sugeri alguns tópicos, como poderia acontecer com outro e qualquer amigo.

Nunes é considerado como espécie de guardião da história das tradições Kariri-Xocó. Ele lê muito e guarda grande parte do que é escrito sobre o seu e outros povos; anota o que dizem os mais velhos. No seu texto, é fácil verificar um pé na raiz e outro nas conversas dos cabeça seca.

No mais, gostaria de referir-me a uma fala de Maria de Lurdes, branca, casada com um Karapotó, gente com a qual Nunes tem relação de família. Na verdade, a Lurdes constrói um conceito de história que tem sua expressão, também, no texto do Nunes e que sigo assim, assim, assim na tentativa de historiar sobre os índios das Alagoas: "A história dos Karapotó é uma história. Uma história bonita e interessante. Já é de descendentes, bisavós, tataravós, de pai, de mãe... Vai passando de geração em geração. E cada um vai contando: meu avô me contava assim, assim, assim... Meu bisavô me contava assim, assim, assim... Meu pai me contava assim, assim, assim... e cada um vai contando" .

* Luiz Sávio de Almeida é professor da Univerisidade Federal de Alagoas. 
social. Na reunião da comunidade, aquele que tem muita parentela é ouvido quando fala, considerado e admirado por todos. Meus pais tiveram dez filhos, mas por destino da vida só sete sobreviveram.

Meu pai fazia parte do Conselho tribal, pessoa de confiança do pajé, nas reuniões que buscavam as soluções dos problemas da aldeia. Ele também era agricultor, trabalhava para os fazendeiros que nossas terras tomaram. Mas criou os filhos como pescador e vendedor de peixe na cidade de Colégio. Minha mãe era ceramista; trabalhava no barro: a produção era vendida na feira local.

Contava meu pai que meu avô Manoel Nunes trabalhava como agricultor nas propriedades dos posseiros, ocupantes da terra indígena, nos atuais municípios de Porto Real do Colégio e São Braz. Os posseiros eram filhos dos antigos arrendatários das terras indígenas, da época das Diretorias dos Índios, que logo após a extinção oficial das aldeias pelo governo Imperial foram loteadas e vendidas aos invasores, já pelo governo da República.

Aos índios expropriados, só restou para habitação uma rua estreita na periferia da cidade de Porto Real do Colégio, onde os fazendeiros se deslocavam para contratar mão-de-obra indígena para trabalhar nas fazendas de plantações de algodão, milho, feijão, arroz nas propriedades das terras alagadas.

O meu avô trabalhava com os indígenas justamente na limpa da lavoura de legumes, com um salário de fome, insuficiente para o sustento da família. Minha avó Júlia trabalhava como meeira nas lagoas de plantação de arroz, onde os proprietários chamavam os índios para aceitarem o contrato de ficar com a metade da produção no final da safra. O dono da lagoa cedia às mulheres a propriedade para plantar arroz, sem ganhar salário. O pagamento era dar a metade da safra e o trabalho para as índias; o proprietário ficava com a outra metade da produção sem o trabalho, despesa alguma com o arroz; só o uso da terra pelos índios; dava direito ao dono da lagoa a $50 \%$ do lucro a custo zero. As índias e as crianças ajudavam as mães: sobravam $50 \%$ da produção com as despesas e o trabalho.

Minha mãe contava que Euclides, meu avô, trabalhava também como agricultor, mas só que era nas terras de vazante do rio São Francisco. As terras de vazante eram aquelas de solo úmido, onde os proprietários também usavam a mão-de-obra barata dos índios no cultivo de mandioca, abóbora, milho e batata. Mas Euclides, além de agricultor, era pescador experiente: possuía a canoa de pesca e os utensílios da profissão. 
Quando era três e meia da madrugada, ele ia ao rio São Francisco pescar os covos para pegar camarão. Ao longo da pesca, continuava com a tarrafa lanceando na pesca de outros peixes: curumatá, piau, lambiá e piranha. Logo após a pescaria, ele retornava para casa com o balaio cheio de peixe, às cinco horas da manhã.

A família arrodeava o balaio para ajudar a tratar os peixes que seriam salgados na gamela; os peixes graúdos eram tirados para a alimentação do dia. Na vazante, ele ia após o café; colocava a enxada nas costas e saía para o trabalho, levando uma cabaça d'água e Jurandir, seu filho mais velho, para ajudar no orçamento familiar.

Maria Pureza, minha avó por parte de mãe, era ceramista; trabalhava em casa, como todas da profissão. Na aldeia, quando uma mãe de família não plantava arroz de meia, a alternativa foi sempre o trabalho com barro. Pureza fazia pote, panela e frigideira na própria casa onde morava, que servia de residência e olaria. As meninas da casa aprendiam com a mãe a arte, para ajudarem o marido a criar os filhos.

Minha mãe, filha mais velha, ajudava minha avó, que lhe passou o segredo da cerâmica; quando se casou, sabia todo o manejo da palhete do coité. Ela contava que viajou muito mais o meu avô Euclides; carregava a louça queimada no forno para a canoa grande de Cícero Catingueira, um branco da cidade; subia ao sertão pelo rio São Francisco vendendo potes e panelas pelas cidades e povoados até o município de Pão de Açúcar.

Na volta trazia farinha, peru, galinha e dinheiro, após uma semana fora de casa. Quando a canoa chegava ao porto defronte a aldeia encalhava; meu avô descia e mandava mamãe chamar as irmãs em casa para ajudar a levar a bagagem; era uma grande alegria, porque todos agora iam ter comida em fartura para os próximos dias.

Mamãe ajuntava, no canto, um cento de potes por semana de trabalho; quando estava com uma fornada pronta, com cerca de 250 objetos diversos, começava meu pai a comprar a lenha para efetivar a queima. O cacique Otávio, que tinha um forno, era sempre o que queimava a louça após fazer a arrumação. Começavam a vir os cambistas (compradores) da cidade, o sr. Manoel de Bilé e a sra. Bina, não-índios, e o dinheiro da produção era pago na hora da entrega.

Minha mãe Lurdes pegava o dinheiro e apresentava a papai para ver o que ia fazer, mas geralmente ele mandava ela comprar umas roupinhas para nós ou alguma coisa que necessitasse. Ela começava de novo a fazer o mesmo trabalho de cerâmica. Tinha índio que descia a Penedo, 
Piassabuçu e Brejo Grande para vender louça de barro. Mamãe mandava uns objetos. A canoa encostava e começavam a embarcar a cerâmica: homens, mulheres e crianças ajudavam no carrego.

Mamãe também sabia fazer lingüiça, que aprendeu com minha avó Pureza. A corda era repleta do produto; tirava para a alimentação do pessoal da casa e a outra parte vendia aqui mesmo, a quem viesse comprar.

Ela me contava, que muitos anos antes da fundação do Posto Indígena Padre Alfredo Dâmaso, as coisas eram muito mais difíceis para os índios. Os brancos da cidade, principalmente a polícia, perseguiam os indígenas, proibindo de dançar o Toré na rua em que moravam. À noite, um pessoal que não sei o nome, chegava na rua dos Índios e mandava que nossos parentes fossem dormir cedo, às seis horas. Não podiam ouvir choro de menino.

Esse pessoal era malvado, espancava índios com chibata, montava no índio (homem) como se fosse animal, com esporas nos pés e feriam aqueles que não tinham quem os acudisse. Certa vez os índios estavam reunidos debaixo de um pé de juazeiro e começaram a dançar o Toré; entre eles havia alguns brancos da cidade observando o fato. No momento da dança em movimento, o índio Pedro Tinga pisou no pé duma mulher branca sem querer e ela caiu fazendo cenas de drama.

Alguém foi dar queixa às autoridades locais; a polícia chegou, acabou com as danças, pegou o índio Pedro Tinga e começou a espancar desde a rua até a delegacia. Arrastaram pelo chão. Os outros índios não puderam fazer nada; não tinham proteção. Ficavam temerosos porque ninguém estava do seu lado. Os índios vieram a ter algum respeito após a fundação do Posto, em 1944.

Meu pai Alírio era conhecido por Peixe Caro pelos brancos da cidade. Quando era de madrugada saía para a margem do rio, a esperar os pescadores chegarem nas canoas; uns eram daqui da cidade; outros moravam no povoado Tibiri e de São Brás. No porto encostavam as embarcações; os balaios eram cheios para levar para casa, começar a negociar o peixe pelo tamanho e qualidade; nessa hora eu acordava com as teimas de vendedor e comprador. Depois do acerto eles iam embora.

Mamãe acordava para fazer o café da manhã e eu ia olhar os peixes. Tinha piranha, aragú, curumatá, dourado, sarapó, curvina, bagre, niquin, piau. A sala estava repleta de peixe. Após o café, meu pai pegava um balaio cheio. Ia vender pelas ruas da cidade. Quando acabava ele retornava para casa, para levar outro carrego. O peixe que ficava e não era vendido 
seco, era tratado e salgado em gamelas para vender aos matutos do interior que vinham à cidade para a feira, na sexta.

Na quinta-feira, papai matava porco para vender na estação ferroviária aos funcionários da Rede e para receber quando saísse o pagamento. Nossa casa tinha fartura; papai sempre andava com dinheiro no bolso e não deixava nada faltar: o alimento, a roupa, o remédio, tudo que uma casa precisava e a sua família.

Meu pai era uma pessoa alegre, gostava de rir. Pegava as crianças e começava a brincar; colocava eu e meu irmão no braço, cantava e pulava. Corria e bulia com os meninos na aldeia. Às vezes dizia: "menino que anda nu, eu capo!" Os meninos saiam correndo sorrindo. As mães diziam: "o que é isso?". Eles diziam: "é o tio Olire; diz que vai capar!" Elas diziam: "é não; ele só tá brincando!”

Quando meu pai vinha da cidade, trazia banana, bala e bagana após vender o peixe. As crianças diziam: "tio Olire, me dê uma banana!" Ele nunca negava; às vezes, até os adultos. Nosso estilo de vida era mais ou menos; meu pai era um batalhador pelo pão nosso de cada dia. Quando ele ia na rua Dr. Clementino do Monte, de frente ao rio, na bodega do seu Joaquim comprar qualquer coisa, eu escapulia atrás dele; quando ele chegava lá, eu chegava também. Ele dizia: “o que é que você quer, José?” Eu dizia: "aquelas cocadas"; ele comprava, me dava e eu saía correndo para casa.

Minha mãe dizia: “já foi atrás de seu pai? Quando nós for almoçá, você nem belisca o comer!" Nessa hora papai chegava e minha mãe dizia: “mas rapaz, você comprou de novo cocada para esse menino!" Ele dizia: "comprei, ele gosta!" Ele era aquele pai que atendia os filhos no que precisassem: carinho, amor, só gritava: essa era a pisa que ele nos dava em caso de desobediência.

Para criar os filhos, Alírio começava a andar pelas ruas da cidade, com um balaio de peixe, aproximadamente $60 \mathrm{~kg}$ de peso na cabeça, gritando: "olha o peixe!" Toda vez que alguém queria comprar, ele tinha que colocar esforçando a carga em baixo. Quando era no verão, aquele calor do sol ele suportava nos paralelepípedos das ruas. Aquele peso diário era rotina só para ver a família numa boa. No inverno, período das chuvas, não parava essa profissão; nunca tinha férias nem frio e nem calor. Toda a cidade o conhecia como um bom pai de família; sua freguesia abrangia todas as classes da sociedade colegiense; foi respeitado do menino ao mais velho. 
$\mathrm{Na}$ época que as lagoas Comprida, Grande, Coité ficavam cheias, o peixe era abundante; o dono prendia o peixe no viveiro. De madrugada começavam a bater na porta. Diziam: "seu Liro, seu Tojal está chamando". Era o empregado da Lagoa Grande. Ele acordava ainda escuro; os cachorros começavam a latir e ele saía para a porta d'água: "Tojal, oi eu!" Ele dizia: "o peixe tá aí; quantos quilos vai querer hoje?" Papai respondia: "vou querer uns 200 quilos". Seu Tojal dizia: "só isso?" Papai rebatia: "sim, eu sou só; vou dar três viagens para casa com esse peixe para começar a vida". O sol começava a raiar; quando eu acordava, em cima da mesa já estava o que seria para o almoço.

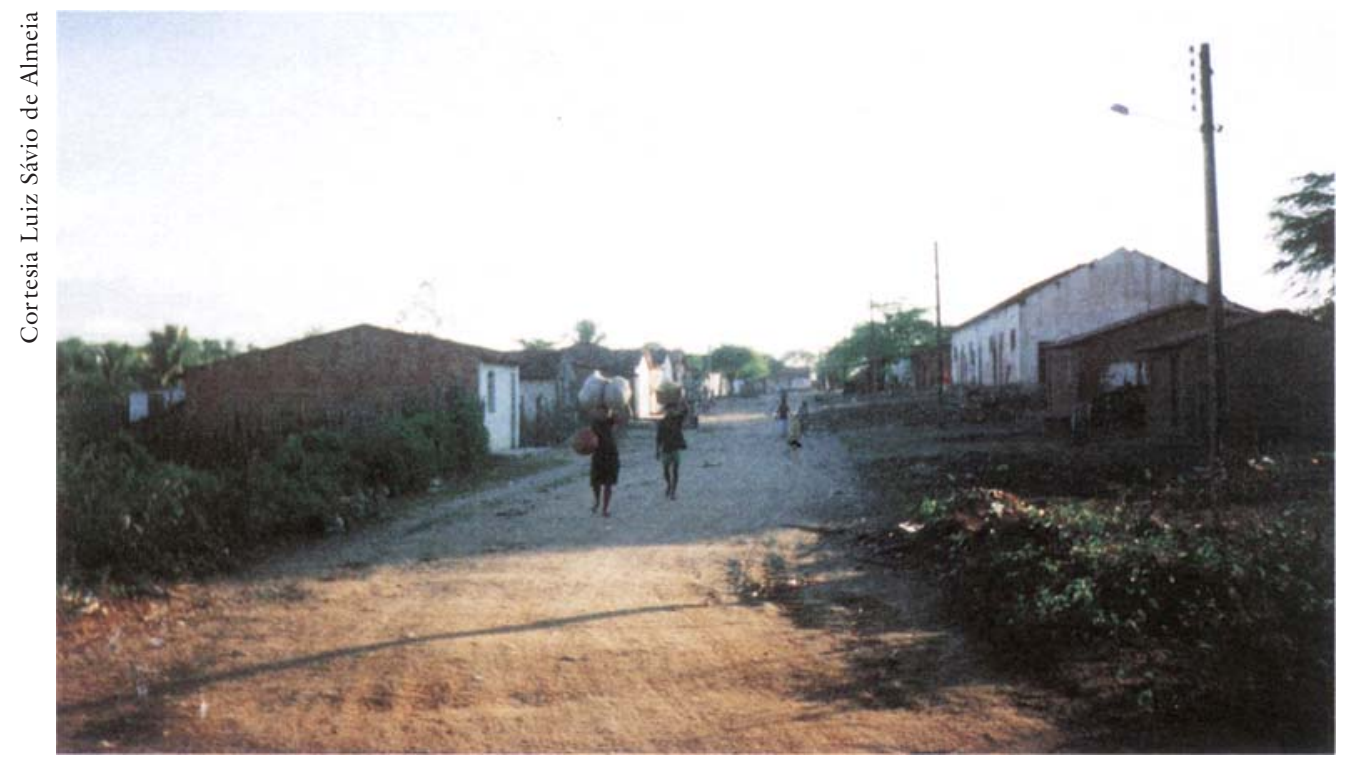

Entrada da aldeia da tribo Kariri-Xocó, no município de Porto Real do Colégio (AL).

Quando nós vivíamos na cidade de Colégio, na rua dos índios, alguns brancos passavam nela, poucos amigos, negociante para vender a prestação, fazendeiros atrás de gente para trabalhar no campo a preço abaixo do mercado; também tinha aqueles com laço de amizade. Muitas vezes jogávamos bola no campinho do Cordeiro com meninos de várias ruas, formando times de pelada. Muita amizade nessa época de 12 anos.

Com o passar dos tempos, cheguei até a visitar a casa deles. Conheci outras pessoas que me perguntavam se eu era caboclo; respondia que era índio. Outros perguntavam quem era meu pai e eu dizia que era filho do Alírio, aquele que vendia peixe. Eles diziam que conheciam meu pai, que ele era gente boa, mas tinha caboclo onde eu morava que eles não gostavam: comem moroba, bobó, andam sujos, bebem cachaça: "aquele 
povo é imundo, cheio de confusão, querem tomar as terras”. Eu ficava ofendido; não gostava quando falavam isso da minha gente. Eu rebatia e discutia com eles.

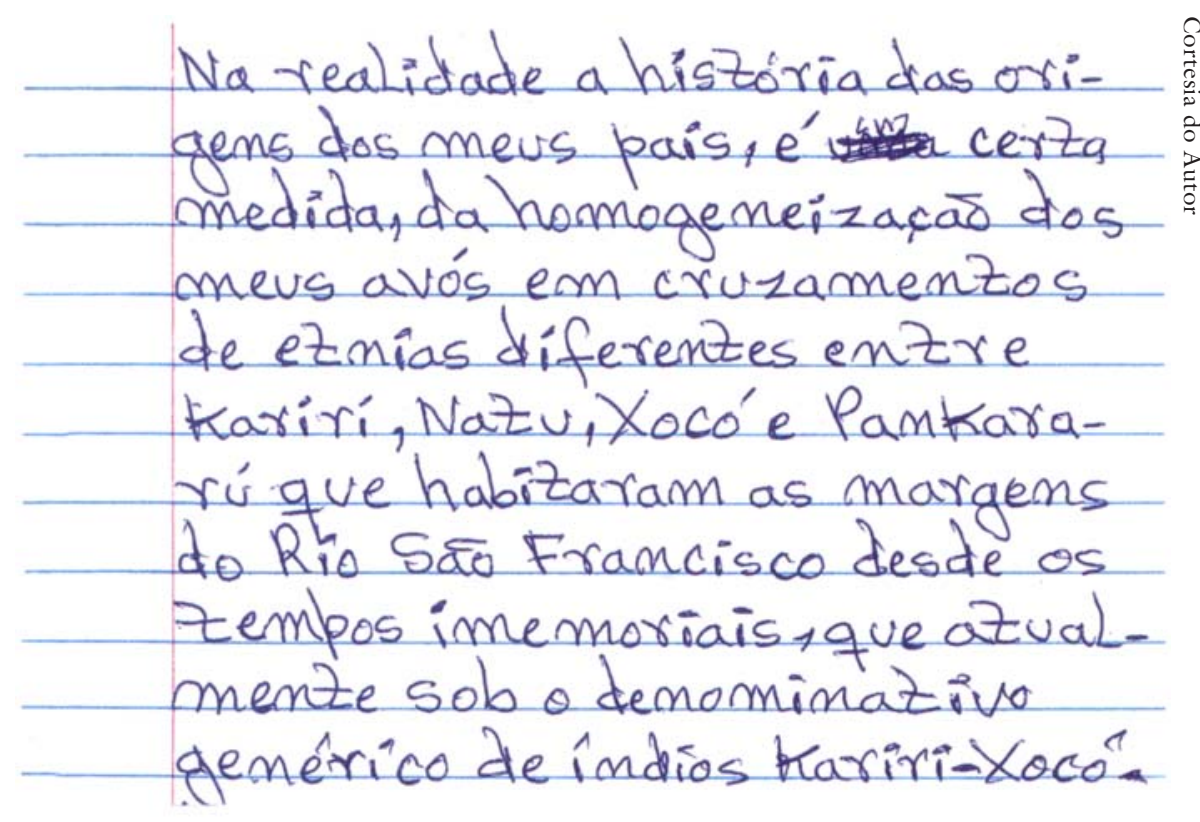

Manuscrito do indio José Nunes de Oliveira

Nesse momento, moderavam: "não é com você não; nós sabemos que tem muita gente de bem como você!" Esse só foi um caso, mas muitas vezes repetiu-se com outras pessoas da cidade com relação aos índios, às vezes, com zombaria, humilhação e até brigas. Mas reconheço que tem pessoas amigas lá e em outros lugares, que nos compreendem.

Nossos quintais na rua dos Índios, cada um tinha uma cerca de madeira no fundo, com um portãozinho ao lado. Dava para a lagoa do Cordeiro, que banhava em círculo os quintais das outras ruas: Santa Cruz, Dr. Clementino do Monte. Na margem da lagoa, a vegetação era um pouco baixa: existia velame, pipeira, ingazeiro, marizeiro e ramagens.

A meninada gostava de brincar de cozinhada, em que cada um dava um pouco para fazer a misturada. As meninas davam as panelas, sal e arrumavam lenha, além de varrerem o pé do velho ingazeiro. Os meninos saiam para o mato para colher frutos silvestres e caçar passarinhos de peteca e apanhar sardão e os outros temperos do mato: tomatinho, alfavaca, ciguleira, maxixe. Os meninos eram quem mais suavam para arranjar a mistura. Mas aquela lagoa era farta, além do peixe; os moradores 
jogavam lixo nos fundos dos quintais e ali nasciam verduras e legumes das sementes jogadas fora.

Quando tudo estava arranjado, os meninos levavam a caça, a pesca e a colheita para que as meninas começassem a cozinhada; elas tratavam do preparo dos alimentos e cozimento. Após as tarefas cumpridas, a menina maior do grupo era quem fazia a divisão, colocando nos pratinhos de barro, ou em cacos de potes quebrados, a comida de todo o grupo, e todos saiam satisfeitos com a brincadeira.

Fazíamos pequenas canoas de raiz de timbauba, colocávamos um pano para pegar corrida na lagoa do Cordeiro. Mas as brincadeiras eram por época; às vezes demorava muito tempo para uma acontecer. No tempo do caju, brincávamos com a castanha: colocando uma encostada na parede, tentávamos acertar e quem conseguia ganhava todas as castanhas jogadas. Quando apareciam os ventos, em certa época do ano, fazíamos pequenos corta-ventos colocados numa vara suspensa com a mão. $\mathrm{Na}$ safra do milho, as meninas brincavam com as bonecas que nascem no pé.

Uma outra brincadeira... Um menino segurava um pedaço de pau lá na beira do rio e gritava: "galinha gorda!" Os outros respondiam: "gorda!" Aí, ele continuava: "para o meio ou para a beirada?" Os outros respondiam: "para o meio!" Ele sacudia o pedaço de pau bem no meio das águas e todo mundo começava a nadar para ver quem era o mais rápido nadador.

Também no rio, tinha a brincadeira de derrubar: eram dois pares de meninos, com o grande colocando o menor nos ombros, ambos em pé, com água na cintura; começava a luta entre os que estavam em cima; quem derrubasse seria o vencedor. A minha brincadeira predileta era atirar com uma lança de madeira para acertar o pé de mamoeiro da minha avó Júlia. Na aldeia só tinha um pareio para disputar comigo: era o meu primo Joelton, filho de Tio Jó (Josival). Gostava muito de fazer um alvo, mesmo no chão e atirar a lança para o alto e acertar no círculo riscado com uma pedra.

O jogo da peteca, feita de palha de milho com pena de pato, era uma roda de meninos batendo com o brinquedo na palma da mão, sem deixar cair. Aquele que derrubasse sairia da brincadeira, ficando no final só dois para disputar a vitória. Eu mesmo não era muito bom nessa brincadeira, perdia todas.

De cima do barranco, avistávamos o rio São Francisco, com suas águas verdes descendo em direção ao mar; olhando para o meio, percebía- 
mos umas pequenas ilhas que as pessoas chamavam de croas de areias claras, com vegetação espinhosa denominada calombi; quem lá ia de canoa, encontrava o capim grande; era o caniço com que nosso povo costumava pescar quando o peixe era abundante. Olhando adiante, na margem direita está o estado de Sergipe; pés de ingazeiras sombreavam o outro lado.

Quando morávamos lá naquela rua dos Índios, não existia o cais de pedra; só tinha o barranco alto, escavado pelas águas do rio ao longo dos séculos; a beira era de uma areia fina, meio amarelada, pequenas pedrinhas alvas como as nuvens do céu; cardumes de peixes remexiam as águas, pulavam como se estivessem brincando. Este rio é um grande espelho do sol e da lua; onde refletem as suas luzes no horizonte estão os pequenos montes; do lado de cá, onde está nossa cidade, só tem casas beirando o rio.

Acima da rua onde morávamos, estavam canoas de pesca amarradas com cordas em troncos fincados n'água; continuando mais além, o morro de São Caetano, marco tradicional de nossa terra. Da calçada do antigo Posto dava para ver a serra da Apreaca.

A escola da aldeia fazia parede com a nossa casa; dava até para ouvir as aulas da professora Terezinha Wanderley, uma branca da cidade de Colégio. Por ansiedade de estudar, pedia a meu pai que queria. Ele, pela minha insistência, foi na mercearia de seu Antônio Donato e comprou um $\mathrm{ABC}$ de cor vermelha e deu para mim. Mamãe foi à escola comigo e falou: "comadre Terezinha, bote o José para estudar com os outros meninos; a vida dele é me aperrear". Dona Terezinha me colocou na turma da manhã; ainda me lembro: as carteiras eram daquelas que acomodavam quatro alunos.

Antes das aulas, tínhamos de dar bom dia à professora, rezar Pai Nosso e Ave Maria. O uniforme era bermuda marrom com suspensórios e camisa xadrez, fornecido pela FUNAI, como também caderno, lápis e borracha, além da merenda escolar: sopa ou leite.

Um ano depois, já estudava a cartilha e começava a formar palavras. $\mathrm{Na}$ hora do recreio ensinavam as brincadeiras da cidade. De manhã, o zelador abria e varria; era o índio Francisco Tamoné (Zé Gatinho) e também chegava a cozinheira, também índia, a velha Marieta.

Quando eu tinha oito anos já estudava na $\mathrm{l}^{\text {a }}$ série e cada vez mais gostava de estudar; meus pais sempre davam uma força; já os outros, tinha deles que seus pais os tiravam da escola para ajudar na cerâmica ou nas roças. 
A pobreza era dominante nessa rua. Muitos deixavam a escola. A professora reclamava ao chefe do Posto, Ademir, mas não adiantava; ele dizia: “o que é que eu vou fazer?” Os alunos, muitos deles, é quem ajudam os pais na agricultura; as meninas também auxiliam as mães a cuidar dos irmãos menores, lavam pratos; outros vão para as lagoas buscar barro para a cerâmica da mãe.

Aquela rua era nossa aldeia, onde o povo morava, onde era possível viver como índio; a união nos dava resistência. Esse lugar foi para mim especial, lá onde nasci e me criei entre parentes: nossa comunidade viva e ativa. Quando um casal precisava de morada, todos se reuniam para construir a habitação, da criança ao mais idoso faziam parte do mutirão. Na limpa das roças nas terras da Colônia, o processo era o mesmo; pessoas se ajudavam.

Nosso povo era amigo na alegria e na dor; quem arrumasse uma coisa que o outro necessitasse, dividia no meio para fome não passar. Em tempos de crise, viajavam dois índios, Pitombo e Zé da Morena, procurando serviço com os fazendeiros Pedro Chaves e doutor Ercílio, todos de Sergipe; na volta à aldeia avisavam que tinham trabalho para um mês inteiro.

$\mathrm{Na}$ doença de alguma pessoa, homens e mulheres iam visitar; o paciente se alegrava mesmo ali sofrendo, lágrimas nos olhos a rolar gemendo. No inverno, água na rua correndo, poças, pedras e lama; meninos na chuva pulando, cantando e patos ali brincando.

Dos momentos ali vividos jamais vão se acabar lembranças, imagens... Vozes, gritos e lamentos estão registrados no tempo. O solo daquela rua guarda um pedaço da nossa história: cacos de panelas, potes e ossos, umbigo de menino novo, restos da cultura material... O sol ainda é o mesmo; estrelas no mesmo lugar; o rio ainda passa, agora beirando um cais... O mundo não para nunca de circular.

Nessa rua dos Índios tinha duas partes em sua definição social: o lado baixo, que era chamado rua de Fora e a parte alta, denomina rua do Alto; havia uma pequena baixa no meio, por onde as águas das lagoas Grande e Cordeiro se encontravam nas épocas da cheia do São Francisco. Nesse ponto, chamava-se Baixinha.

No alto moravam Antônio Tingá e Manoel Preto, melhores cantadores de Toré. Firmino Pires, casado com Selé, irmã de meu avô Euclides também morava lá. Firmino Pires, foi o melhor piloto de canoas; era o filho mais novo do antigo cacique Inocêncio Pires. Ainda no alto 
morava Lorinda, anciã de grande sabedoria, filha de Nezinho e bisneta de Pedro Lolaço.

Na rua de Fora morava Analbertino, tio de minha avó Júlia; também era filho de um ancião muito respeitado. Perto dele morava o cacique Otávio, casado com Iria, maior rezadeira da região; todos os dias chegava em sua casa muita gente de fora para ser curada das doenças. Uma das melhores ceramistas era a velha Luiza, que decorava com pinturas de argila branca as mais belas figuras nos potes.

O cacique Otávio Queiroz Nidé era irmão do pajé Francisquinho, por parte do pai Manoel de Queiroz, bisneto de João Maromba, chefe religioso dos Xocó entre 1899 a 1913. Manoel de Queiroz, portanto, era filho de Gregório Maromba, um dos filhos de João Maromba. A liderança de Otávio teve início após sua escolha, em 1944, após a morte do antigo cacique Kariri Jonas, também seu parente. Todos os índios da aldeia tinham uma atenção especial ao cacique Otávio, porque sua dedicação na tradição o tornara respeitado internamente e dera exemplo à comunidade indígena: o cacique é aquele que ouve as decisões dos órgãos internos (Conselho Tribal), chefes de família... Junto com o pajé examina o ponto de vista viável, executando a ordem estabelecida.

Numa aldeia, o cacique deve visitar todas as casas, ouvir problemas ao longo do tempo, dar atenção às crianças, aconselhar os mais inexperientes, conscientizar que o povo indígena só sobrevive coletivamente em união das pessoas. Otávio, através de sua observação social, dava nomes às pessoas da aldeia de acordo com a característica comportamental do indivíduo a denominar. Por exemplo, um menino que tomava banho no rio e era muito veloz na habilidade de nadar, o cacique dava-lhe logo o apelido de piaba (peixe do rio) e todas as pessoas reconheciam socialmente a identificação, denominação do indivíduo. Agora eu digo que cada povo tem o doutorado em sua cultura, porque somente ele pode saber sua origem, o que quer, o que sente, o que busca e para onde vai seguir.

O homem que mais trabalhava em madeira era José Taré, grande artesão que fazia as maiores obras de arte, até por encomendas: tacapes, carrancas, móveis. Ele tinha a marcenaria como profissão. Otávio, maior contador de história indígena da época, chegava lá em casa à noite, como os outros velhos, para contar fatos passados e eu ficava ouvindo - deitado numa esteira de piripiri - até dormir. Alí ficavam até 11 horas da noite; quando a lua estava alta, as pessoas iam se acomodar, dormir no silêncio da noite, a não ser algum menino que chorava para mamar. Numa aldeia, 
as mulheres conhecem as crianças mesmo sem vela, só basta ouvir seu choro e uma diz: "aquele é fulano, filho de fulana".

Na esquina da rua morava o chefe Paulo Austragésimo da FUnAI, no próprio Posto Indígena, do qual tenho boas recordações por ser uma pessoa amiga das crianças. Introduziu na escola o esporte do vôlei, a quadrilha junina, o forró, o desfile de 7 de Setembro e a premiação dos alunos, do $1^{\circ}$ ao $3^{\circ}$ colocado pelas melhores notas no final do ano pela aprovação. Na lagoa do Cordeiro em época de pescaria, Laudilina, irmã do pajé Francisquinho, era a índia que mais pegava peixe de mão: cará, traíra e outros.

Resistir era preciso; Josival, irmão de meu pai, nunca perdeu uma briga na cidade com aqueles que queriam maltratar os índios, mas nunca matou ninguém; só dava uma lição nos brancos provocadores.

Na época da folia do carnaval, na zoada, a cidade de Colégio não parava nem de dia e nem de noite. Homens mascarados, cada um a seu modo, outros banhados em pó de maizena, acompanhados sempre por uma batucada. Andavam de rua em rua; pela nossa também passavam os rapazes da aldeia. Nossa rua era modesta; os mais velhos só observavam; muitos nos aconselhavam, falavam que essa festa não era abençoada, que o rebuliço foi o cão que inventou. Diziam que muitos deles se fantasiavam só para dar uma lapada; não era bom que se participasse disto.

A colheita das roças coincidia com a festa junina, milho verde, feijão e abóbora: tempo de fartura. Todos os anos o rio enchia com as enxurradas; desciam rolos de pau pela força da água, meninos e meninas pegando para fazer as fogueiras troncos, galhos, árvores que desciam do sertão.

Em noite de São João, os pais compravam roupas para os filhos, traques, chuvinha e bombas. As mulheres faziam canjica, pamonha, mungunzá; na fogueira, carne e milho verde na brasa. Na escola, as carteiras eram tiradas da sala e às 8 horas começava o Toré; durava a noite toda, até amanhecer. No Toré estavam pessoas de todas as idades.

Os índios que moravam na Colônia também vinham participar. Não tinha nada de forró. A rua dos Índios estava toda iluminada, as fogueiras acesas, os mais novos soltavam fogos. Todos os índios de roupa nova. Em nossa casa, tudo já estava providenciado: arroz doce, peixe assado, roupa de meus irmãos. Papai comprava pano em Propriá: a costureira era Lizete, branca da cidade de Colégio. Nesse dia de festa, papai ia buscar a roupa na medida, colocava em cima da cama e todos nós vestíamos logo cedo para andar na rua. 
A festa de Natal comemora o aniversário de Cristo e era visto na rua dos Índios com grande respeito. Os pais preparavam os filhos com a melhor roupa para a missa na Matriz de Nossa Senhora da Conceição. Antes da Missa do Galo começava o Pastoril no coreto da praça Godilho de Castro, centro da cidade, bem em frente à Igreja. As moças que faziam as cenas eram todas brancas. Papai Noel distribuía presentes às crianças na praça. Eu ganhei um carrinho de plástico azul; fiquei muito contente. A meia-noite começava o foguetório; eu ficava com medo e tinha pavor de fogos de artifício. Mamãe dizia que eu não devia chorar: a noite de Natal era para sorrir, pois foi nessa noite que Jesus nasceu.

Nossa professora Terezinha, nas aulas ministradas na escola da aldeia, ensinava aos alunos orações cristãs; incentivava meninos para a missa do sábado e do domingo. Como eu estudava na $3^{\text {a }}$ série e tinha 10 anos, acompanhava a turma para a Igreja. O vigário da paróquia era o padre Hildebrando. De manhã, os sinos tocavam e mamãe me acordava: "José, levante! Vai tomar um banho no rio! Tome o café para ir à missa! O sino já deu a primeira badalada!”

Pedia-lhe a benção e ela me abençoava. Vestia a roupa, calçava as congas azuis com uma meia branca. Papai me dava moeda para comprar pipoca. Meu primo César Girir chegava lá em casa com os meus colegas de classe: Lenoir, Djalma, Vilma... Alguns iam acanhados por terem uma roupinha fraca com relação aos brancos da cidade, sempre bem vestidos e calçados.

Nossa família nunca perdeu uma procissão; muitos índios também faziam o cortejo, junto com o pessoal da cidade, a começar na Semana Santa: na participação nas Estações, Senhor dos Passos eu ia junto com meu pai e a outra procissão seguia outras ruas com as mulheres acompanhando Nossa Senhora das Dores; minha mãe ia nesse grupo, com algumas índias, junto à imagem.

No mês de agosto, dia 16, era a procissão de São Roque, o padroeiro da cidade desde 1911, quando teve uma cólera na região de Colégio, o padre fez uma promessa e a epidemia acabou. Desde essa época São Roque ficou como padroeiro pela graça alcançada. Houve muitas vítimas e entre elas os índios.

No dia 29 de novembro começava a primeira noite de novena, festa da padroeira da cidade, organizada por cada classe social e com direito a uma noite. Esse período era aguardado com muita ansiedade pela sociedade colegiense. Todo mundo do município fazia economia para comprar 
boas roupas e ter dinheiro no bolso para gastar na festa. A procissão era no dia 8 de dezembro, às três horas da tarde, e a noite era dedicada aos índios.

Na praça Rosita de Góes Monteiro ficava o parque de diversões; meu pai sempre nos levava para andar nos aviões, patinhos e roda gigante, além de comprar baganas após o encerramento da procissão.

O Ouricuri, na minha época de menino, era uma grande mata fechada que cobria vasta área dos atuais municípios de Porto Real de Colégio e São Brás, no território indígena imemorial. Nessa floresta existiam várias espécies de vegetais e animais em abundância. $\mathrm{O}$ caminho que levava ao interior da mata era uma pequena vereda, onde existia a aldeia tradicional com casas de palha, em que nosso povo ficava vários dias no ritual religioso indígena. Esse cerimonial é sagrado; não pode ser revelado aos brancos; somente aos índios que nascem na tradição de preservar a cultura original de nosso povo indígena Kariri-Xocó. Além dessas tribos, outros grupos indígenas podem assistir ao ritual: os Fulni-ô, TinguiBotó e parte dos Karapotó que vivem na área.

Eu saía para o interior da mata junto com Joelson, o meu amigo e primo, à procura de frutos silvestres. O cheiro da gabiroba, ubáia, maracujá nos fazia identificar onde encontrar. Árvores altas e sombrosas, como o angico, a baraúna, dominavam a paisagem. O som dos pássaros nos pedia para escutar seus cantos. Andar nessa floresta exigia muito cuidado; cobras ficavam escondidas nas folhagens, aranhas e escorpiões eram o perigo maior.

Hoje está diferente, mata devastada, os animais estão sumindo, lenhadores e caçadores ofenderam a natureza. Fico triste quando olho; aquela mata linda que existia pede socorro para as pessoas replantar a vegetação, preservar o que existe para os animais novamente voltarem. $\mathrm{O}$ Ouricuri é conservar o que Deus nos deu.

Quando eu tomei consciência de estar no Ouricuri senti uma diferença; morávamos numa rua sem mata e o barulho era constante: carros buzinando, músicas nos rádios, pessoas estranhas sempre passando nesse beco em aperto. Quando eu era criança, lembro que uma vez chegou o meu cunhado Juarez, parou na porta com uma carroça de burro, desceu e disse: "dona Lurde, seu Alírio mandou levar as coisas para o Ouricuri”.

Subimos na rua ladeirada; os índios também estavam no mesmo reboliço, carga na cabeça, trouxa e meninos nos quartos, esteiras debaixo do braço. Saímos pela rua da Aurora, pegamos um caminho ermo; o sol estava se pondo... Passamos pela cidade; as luzes cada vez se afastavam. 
Chegamos numa mata escura, a estrada era como quê um túnel de ramagem. Perguntava a Juarez: "que canto é esse?" Ele me dizia: "não tenha medo; isso é a coruja!”

Finalmente nós estávamos numa nova aldeia de forma circular, as casas eram de palha e não tinham compartimentos. Perguntei a ele porque nós vínhamos para ali e ele respondeu: "Zé, aqui é o Ouricuri; muitas vezes você veio quando era mais pequeno!" Foi aí que tomei consciência de que aquele lugar não era estranho. Ele foi logo nos descendo, as coisas tirou também, colocou num ranchinho de palha e depois a mamãe chegou.

A mamãe me dizia que no tempo dela o mato era maior; cobras atravessavam a estrada, raposas também cruzavam, o dia parecia noite pela sombra das árvores. Nossos ranchinhos de palha de Ouricuri ou de arroz, o gado dos fazendeiros quando nós não estávamos lá derrubava a casa e comia a cobertura; em nossa chegada, tudo estava no chão.

Em noite de inverno se fazia um amparo com esteira de periperi para agasalhar os meninos; a chuva não parava, a água escorria por debaixo, nós agüentávamos por amor à tradição. Crianças ficavam roxas de tanto frio que passavam; se fazia um foguinho para enxugar a roupa molhada, aquilo era uma benção; ninguém vivia doente, as pessoas eram sadias porque estavam acostumadas.

Aqui, nos problemas de saúde ocorridos com as crianças, as mães sempre resolvem, quando a doença é simples, com chás de ervas ou uma simpatia. A papeira, sempre se cuidava com casinha de maribondo feita de barro nas paredes; quebrava em pedaços e fazia uma pasta colocando no rosto. Pronto, esse era o remédio.

Para o sarampo se arrumava fezes de cachorro; estando seca, amarrava em um paninho e colocava para esquentar numa panela com água; era só tomar o chá. A frieira que se dá nos pés, mãos, não tem complicação, pois a pessoa mesma se cuida: é só mijar no pé. Em caso de diarréia, toma-se o chá da folha de goiabeira, pegando as folhas do olho ou raspa de arapiraca. Dor de cabeça, ela, minha mãe, sempre cuidava com matacabra, amarrando na cabeça. Casca de aroeira é bom para cicatrização. Para surdez, é bom coçar o ouvido com rabo de tatu; na queimadura, clara de ovo.

José Nunes de Oliveira é índio da tribo Kariri-Xocó, localizada no município de Porto Real do Colégio, Alagoas. 